\title{
6. DIAGENETIC AND HYDROTHERMAL MINERAL ALTERATION OBSERVED IN IZU-BONIN DEEP-SEA SEDIMENTS, LEG $126^{1}$
}

\author{
Kazue Tazaki ${ }^{2}$ and William S. Fyfe ${ }^{3}$
}

\begin{abstract}
Sediments and rocks recovered during Ocean Drilling Program Leg 126 at Sites 792 and 793 in the Izu-Bonin forearc basin are described with a primary focus on clay mineralogy. Evidence for diagenetic hydrothermal alteration processes is present in the upper Oligocene to lower Miocene sediments at these sites. The vitric and pumiceous sand/sandstone and pumiceous gravel contain high concentrations of smectites, zeolites, and gypsum. Microscopic observations show that the volcanic glass and feldspars have been altered to smectites and zeolites. The authigenic mineral assemblages indicate that these minerals resulted from precipitation from circulating fluids, as well as from the alteration of glass and feldspar under temperature conditions that may have reached $200^{\circ}-300^{\circ} \mathrm{C}$. Mineral assemblages in microfractures display thermal gradients that possibly reflect cooling effects.
\end{abstract}

\section{INTRODUCTION}

To determine the history of forearc sedimentation, arc volcanism, microstructural deformation, and plate motion, and the petrology of the underlying basement, nine holes were drilled at three sites (Sites 787, 792, and 793) during Leg 126 in the Izu-Bonin forearc (Taylor, Fujioka, et al., 1990). The cores collected at these sites provided a unique opportunity to study the complete forearc sequence through the sedimentary section into the volcanic basement.

The objectives of this mineralogical study of Izu-Bonin forearc sediments were (1) to determine temporal bulk and clay mineralogy variations, (2) to relate any changes in clay mineralogy to chemical and physical characteristics of the sediments, and (3) to document diagenetic and hydrothermal alteration processes of volcanic glass and feldspar. The qualitative mineralogical descriptions of the sediments recovered during drilling have been presented in the individual site reports found in the Leg 126 Initial Reports volume (Taylor, Fujioka, et al., 1990). In this paper, the shipboard semiquantitative $\mathrm{X}$-ray results are described in detail along with electron microscopic observations from shore-based research.

\section{SAMPLES AND METHODS}

A total of 44 samples from Holes 792A, 792B, 792D, and 792E and a total of 132 samples from Holes $793 \mathrm{~A}$ and $793 \mathrm{~B}$ were analyzed by X-ray powder diffraction (XRD) methods aboard the JOIDES Resolution. The samples were analyzed on a Phillips ADP $3520 \mathrm{X}$-ray diffractometer using $\mathrm{CuK} \alpha$ radiation with $\mathrm{Ni}$-filter, a count time from 1 to 2 seconds (s), and an accelerating voltage of $40 \mathrm{kV}, 35 \mathrm{~mA}$ (see "Explanatory Notes" chapter in the Leg 126 Initial Reports [Taylor, Fujioka, et al., 1990] for further details).

The samples to be X-rayed were ground in water in a porcelain mortar; the resulting finest fraction was then decanted, and the suspension was allowed to settle. After about $0.5 \mathrm{hr}$, the supernatant was pipetted and sedimented onto a glass slide to produce oriented samples. Examination of the powder diffractograms of these samples revealed peaks for clay minerals, zeolites, feldspars, and volcanic glass in the interval between $2^{\circ}-65^{\circ} 2 \theta$. Ethylene glycol was then

\footnotetext{
'Taylor, B., Fujioka, K., et al., 1992. Proc. ODP, Sci. Results, 126: College Station, TX (Ocean Drilling Program).

${ }^{2}$ Department of Geology, Shimane University, Matsue, Shimane Prefecture 690, Japan.

${ }^{3}$ Department of Geology, University of Western Ontario, London, Ontario N6A 5B7.
}

added to the prepared slides to aid in the identification of smectite in the interval between $2^{\circ}$ and $30^{\circ} 2 \theta$. Enough ethylene glycol was added to air-dried material to make it visibly moist. Relatively small amounts (5\%) of smectite can be identified with this technique. Semiquantitative estimates of major mineral and clay mineral abundances were determined using the strongest peak intensity (measured in counts per second; cps) of each mineral. Smectite and chlorite abundances were estimated after glycolation. Minerals characterized by a strong $7-\AA \AA$ peak intensity (kaolin and chlorite) were identified after the sample was treated with acid.

To refine the XRD estimations of mineral abundances in the samples, scanning electron (SEM) and transmission electron (TEM) microscopy analyses were conducted using a JEOL-JSM T220A scanning electron microscope (accelerating voltage of $15 \mathrm{kV}$ ), and a JEOL-JEM 2000EX transmission electron microscope (accelerating voltage of $160 \mathrm{kV}$ ).

\section{RESULTS}

\section{X-ray Powder Diffractions}

Qualitative descriptions of the XRD data for samples from Sites 792 and 793 that were analyzed aboard the JOIDES Resolution during Leg 126 are summarized in the individual site reports in the Initial Reports volume (see Taylor, Fujioka, et al., 1990). The semiquantitative mineral analyses (in cps) of the Site 792 and 793 samples are plotted against depth below the seafloor in Figures 1 and 2. Examples of the strongest peak intensities used to determine the counts per second value for the minerals are shown in Table 1 .

Volcanic glass abundance was estimated from the intensity of the broad peak at $3.0-3.3 \AA$ and confirmed by optical observation in thin sections. The color of the volcanic glass changes from clear in the upper (younger) part of each section to brown and green in the deeper (older) intervals. At Site 792, the abundance of volcanic glass decreases and the abundance of glauconite and palagonite (10- $\AA$ minerals on Fig. 1) increase with depth. At Site 793, no definitive downhole trend can be seen in the concentration of volcanic glass.

Zeolites are present in middle Miocene and older intervals at Site 792 (below 330 mbsf; Fig. 1), whereas at Site 793 zeolites are found only in Oligocene sediments (below 750 mbsf; Fig. 1). Analcime, phillipsite, heulandite, and clinoptilolite are common at both sites. Wairakite was also identified at Site 792, suggesting higher postdepositional temperatures. Gypsum, zeolite, and prehnite were observed in microfractures at both Sites 792 and 793 .

Calcite counts range from 10 to $600 \mathrm{cps}$ at Site 792 and from 10 to $1500 \mathrm{cps}$ at Site 793. Counts in the nannofossil layers range up to 


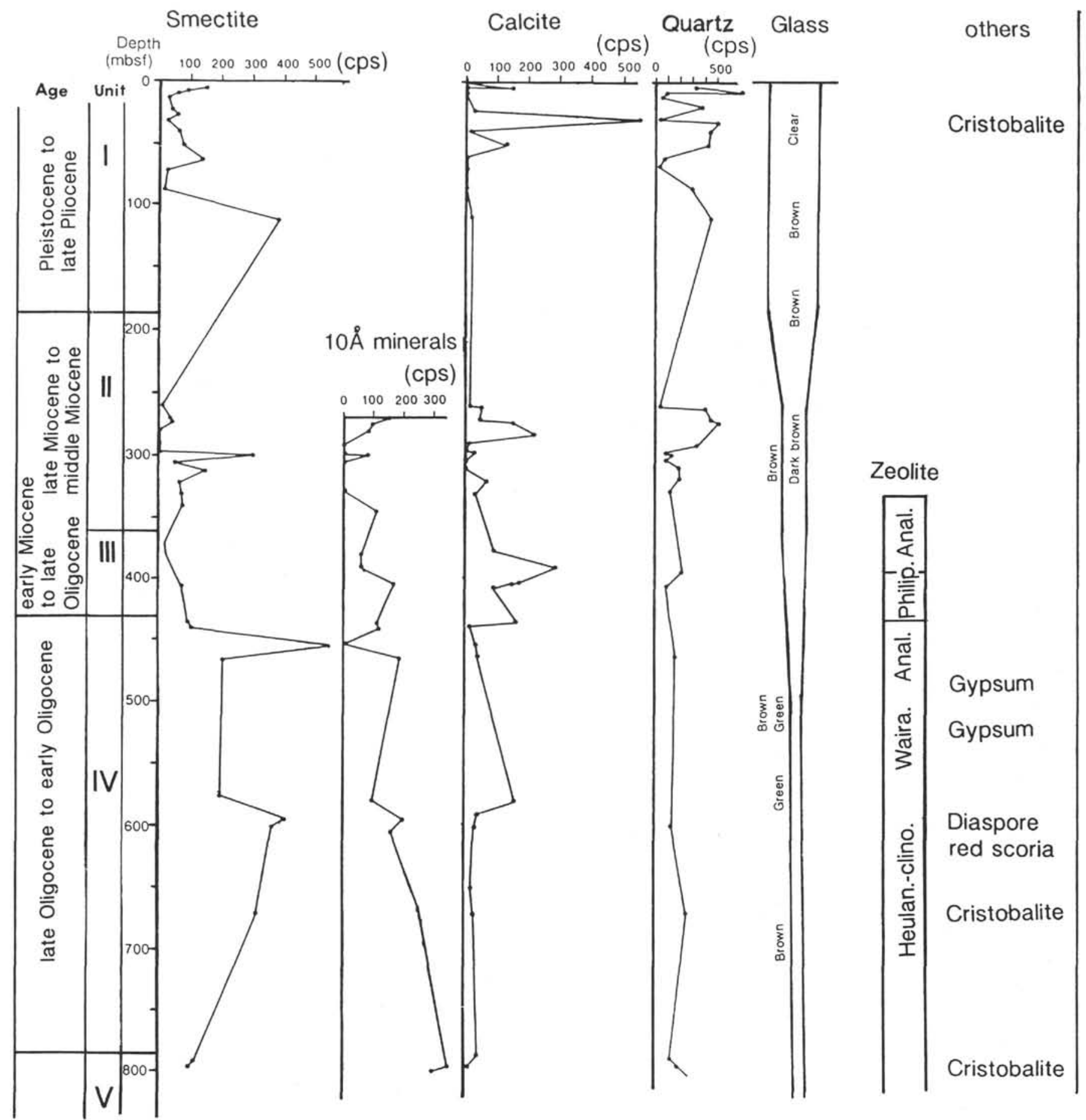

Figure 1. Variation of semiquantitative XRD data vs. depth at Site 792. The strongest peak intensity is plotted as counts per second for smectite, calcite, quartz, and $10-\AA$ minerals, whereas glass, zeolite, and chlorite are qualitatively shown. Anal. = analcime, philip. = phillipsite, waira. $=$ wairakite, and heulan.-clino.= heulandite-clinoptilolite.

$1500 \mathrm{cps}$ and are generally lower (from 10 to $500 \mathrm{cps}$ ) in vitric, pumiceous, or clayey sediments. Dolomite also occurs near 1300 mbsf at Site 793 .

Smectite varies from 10 to $500 \mathrm{cps}$ at Site 792 and from 10 to 1900 cps at Site 793. Smectite concentrations generally are highest in the lowest sections at each site (lower to upper Oligocene). Very high smectite contents (up to $1900 \mathrm{cps}$ ) are seen at 880,1140 , and around 1480 mbsf at Site 793.

Most smectites at Sites 792 and 793 exhibit a wide range of (001) $d$-spacings from 14.9 to $17.2 \AA$, but their $(060) d$-spacing only varies between 1.50 and $1.51 \AA$, indicating that dioctahedral smectite is the dominant smectite phase present. There are very few trioctahedral smectites in samples from these two sites.

Feldspars are present throughout the section at both sites. Enough feldspar material was present at Site 793 to differentiate sodium and calcium plagioclase feldspars (Fig. 3). The plagioclase has been altered to clay minerals in many samples (see "Microscopic Observation" section below). Chlorite is seen at both sites. At Site 793, for instance, chlorite is 


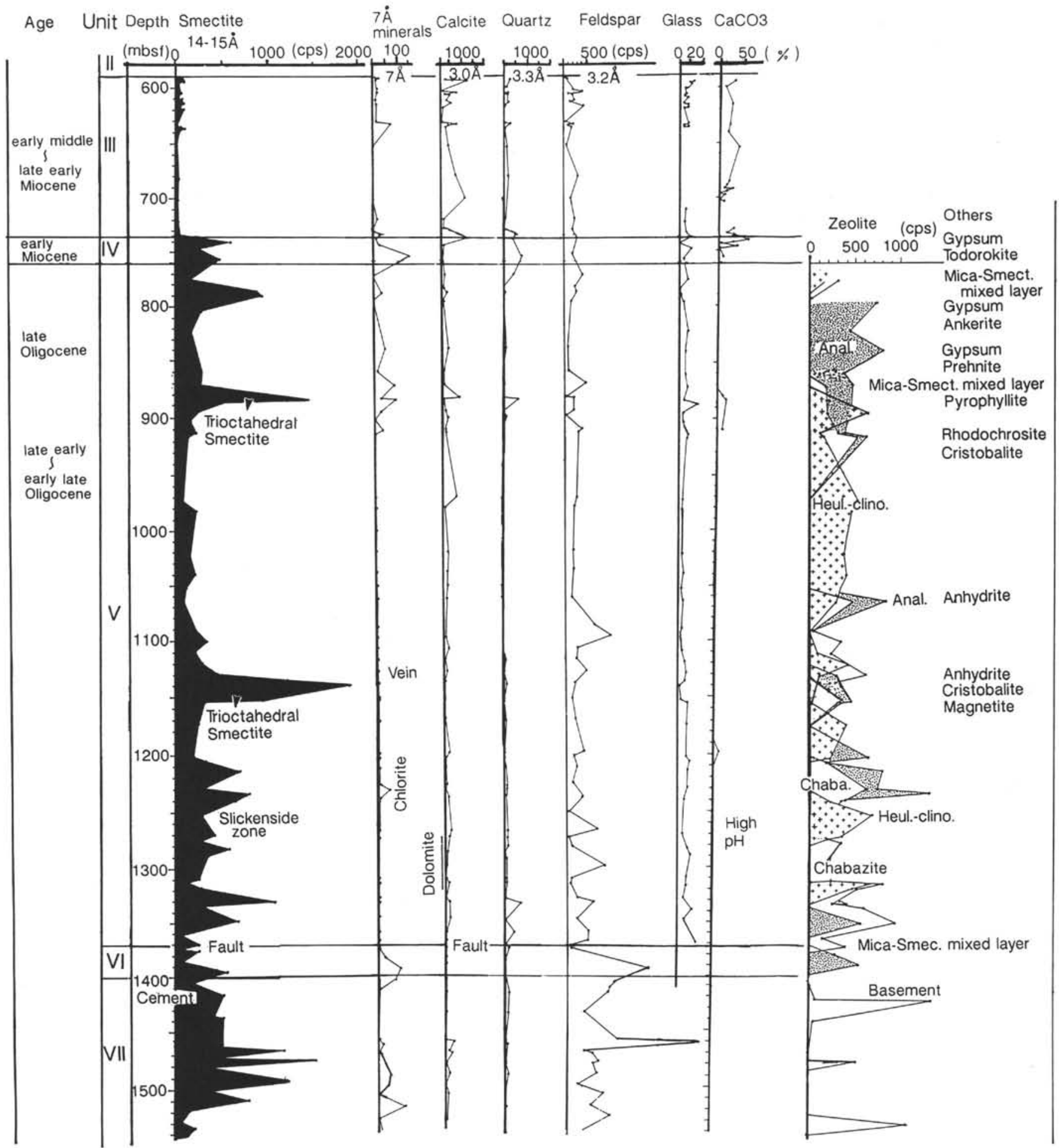

Figure 2. Variation of semiquantitative XRD data with depth at Site 793. The strongest peak intensity is plotted as counts per second for smectite, 7- $\AA$ minerals, calcite, quartz, feldspar, and zeolite. $\mathrm{CaCO}_{3}$ data are from shipboard bulk chemical analyses. Glass abundance data from shipboard smear-slide analyses. In the zeolite column, dotted pattern = analcime (anal.); crosses = heulandite-clinoptilolite (heul.-clino.); and white areas = chabazite (chaba.). 


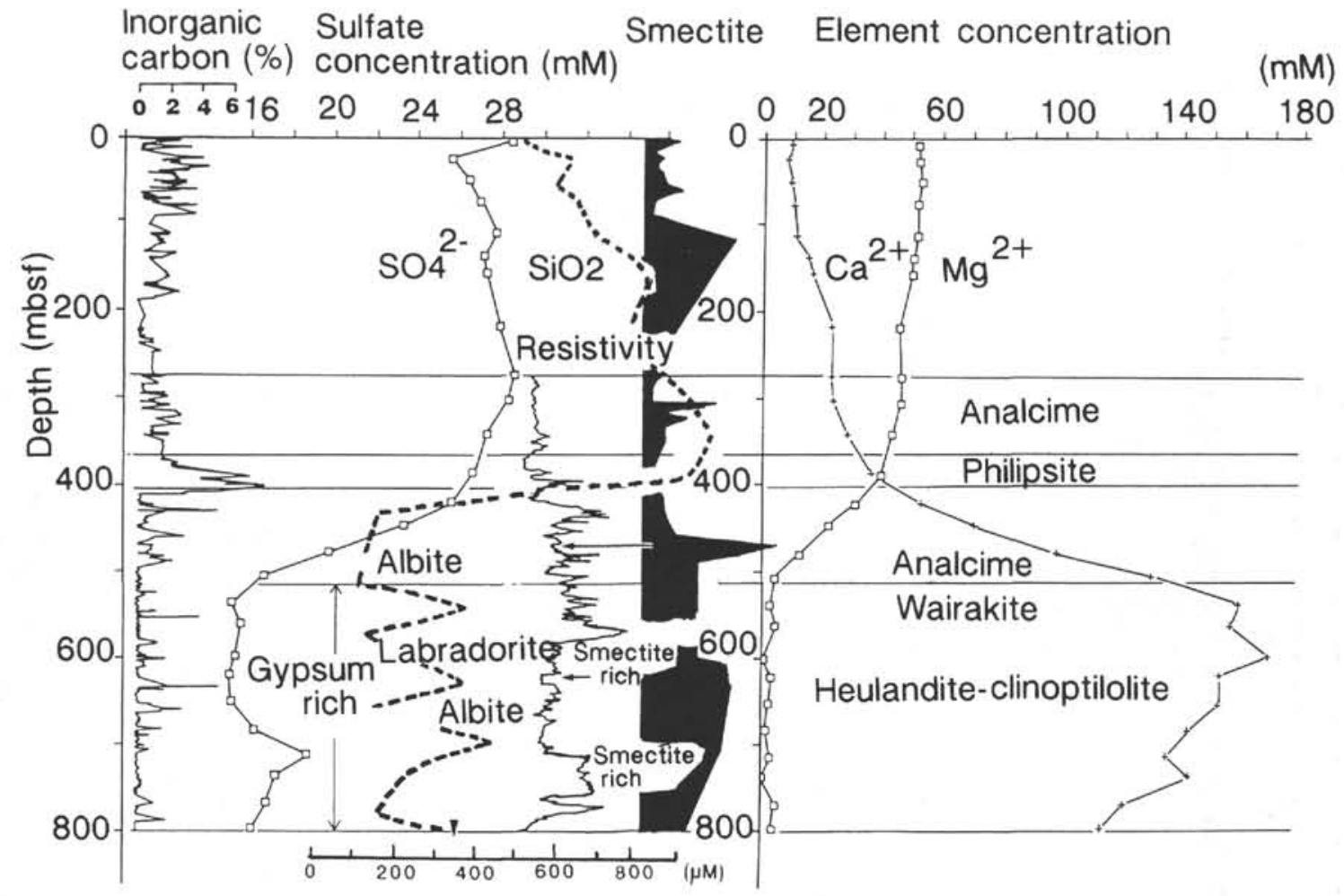

Figure 3. Comparison of characteristic minerals with pore-water chemistry and physical properties data from Site 792.

Table 1. Examples of the strongest peak intensity used to determine the cps value for each mineral in Hole 793B.

\begin{tabular}{|c|c|c|c|c|c|c|c|c|c|c|c|c|}
\hline \multirow{2}{*}{$\begin{array}{l}\text { Core, section, } \\
\text { interval }(\mathrm{cm})\end{array}$} & \multirow{2}{*}{$\begin{array}{l}\text { Depth } \\
\text { (mbsf) }\end{array}$} & \multirow[b]{2}{*}{ Unit } & \multirow[b]{2}{*}{ Texture } & \multicolumn{3}{|c|}{ Clay minerals } & \multirow{2}{*}{$\begin{array}{l}\text { Calcite } \\
0.30 \mathrm{~nm}\end{array}$} & \multirow{2}{*}{$\begin{array}{l}\text { Quartz } \\
0.33 \mathrm{~nm}\end{array}$} & \multirow{2}{*}{$\begin{array}{l}\text { Feldspar } \\
0.32 \mathrm{~nm}\end{array}$} & \multirow{2}{*}{$\begin{array}{c}\text { Analcime } \\
0.34 \mathrm{~nm}\end{array}$} & \multirow{2}{*}{$\begin{array}{c}\text { Chabazite } \\
0.29 \mathrm{~nm}\end{array}$} & \multirow{2}{*}{$\begin{array}{c}\text { Heulandite } \\
0.89 \mathrm{~nm}\end{array}$} \\
\hline & & & & ${ }^{\mathrm{a}} 1.4 \mathrm{~nm}$ & $1.0 \mathrm{~nm}$ & $0.7 \mathrm{~nm}$ & & & & & & \\
\hline $126793 \mathrm{P}$ & & & & \multicolumn{9}{|c|}{ Counts per second } \\
\hline $29 R-4,60$ & 859.8 & V & Fine-grained sandstone & 480 & $\mathrm{Tr}$ & 55 & 210 & 96 & 454 & 408 & 210 & 190 \\
\hline $30 \mathrm{R}-5,45$ & 870.9 & $\mathrm{~V}$ & Very fine-grained siltstone & 1467 & $\mathrm{Tr}$ & 30 & 713 & $\mathrm{Tr}$ & $\mathrm{Tr}$ & - & - & - \\
\hline $31 \mathrm{R}-7,10$ & 883.1 & $\mathrm{~V}$ & Very fine-grained sandstone & 231 & - & 10 & 256 & $\mathrm{Tr}$ & 237 & 671 & 272 & 123 \\
\hline $32 \mathrm{R}-1,3$ & 883.7 & V & Very fine-grained sandstone & 296 & 20 & 12 & 26 & 420 & 10 & - & 26 & 23 \\
\hline 58R-5, 20 & 1140.2 & V & Very fine-grained sandstone & 1918 & 10 & 62 & 182 & 117 & 182 & 339 & 139 & - \\
\hline $59 \mathrm{R}-7,20$ & 1152.8 & V & Very fine-grained sandstone & 986 & 61 & 25 & 164 & 38 & 104 & 462 & 369 & 61 \\
\hline $60 \mathrm{R}-1,107$ & 1154.3 & $\mathrm{~V}$ & Crystal-vitric sandstone & 342 & 12 & 10 & 151 & 58 & 130 & 353 & 310 & 12 \\
\hline
\end{tabular}

Note: $\mathrm{cps}=$ counts per second, $\mathrm{Tr}=$ trace, and $-=$ not measured.

"The strongest peak intensity that we used to determine the counts per second value for each mineral.

present in significant quantities above 920 mbsf (upper Oligocene) but rarely seen below that level. Other $10-$ and $7-\AA$ mineral abundances were low at Site 793 . Significant $10-\AA$ mineral concentrations, however, are present in the Oligocene section at Site 792.

\section{Chemical and Physical Properties: Comparison with Mineralogy}

The chemical and physical properties of the sediments at Sites 792 and 793 have been reported in detail elsewhere (Leg 126 Shipboard Scientific Party, 1989; Leg 126 Shipboard Drilling Party, 1989; Gill et al., 1990; Pezard et al., 1990). In Figures 3 and 4, various physical and chemical profiles presented in those studies are shown with the downcore variations in the mineral concentrations at Sites 792 and 793, respectively. At Site 792 (Fig. 3) these properties are more or less constant at depths shallower than $400 \mathrm{mbsf}$ but change sharply below that depth. Below $400 \mathrm{mbsf}$ inorganic carbon contents increase, pore-water $\mathrm{SiO}_{2}, \mathrm{SO}_{4}^{2-}$, and $\mathrm{Mg}^{2+}$ contents decrease and pore-water $\mathrm{Ca}^{2+}$ contents increase. These data, along with the mineralogical data, suggest that hydrothermal alteration is prevalent below $400 \mathrm{mbsf}$. For example, gypsum-rich sediments between 400 and 800 mbsf correlate well with the low sulfate concentrations in the pore waters. In addition, physical property variations also reflect the altered mineralogy; low resistivity is associated with smectite-rich intervals (see arrows in Fig. 3).

At Hole 793B, the general downhole trend in smectite content correlates with general downhole trends in chemistry $\left(\mathrm{SiO}_{2}, \mathrm{Mg}^{2+}, \mathrm{SO}_{4}^{2-}, \mathrm{Ca}^{2+}\right.$, and $\mathrm{Cl}^{-}$concentrations in the pore water), seismic velocity, and volume magnetic susceptibility (Fig. 4). The large change in all of these mineralogical, chemical, and physical data sets at $750 \mathrm{mbsf}$ indicates hydrothermal alteration is prevalent below this depth at this site. 


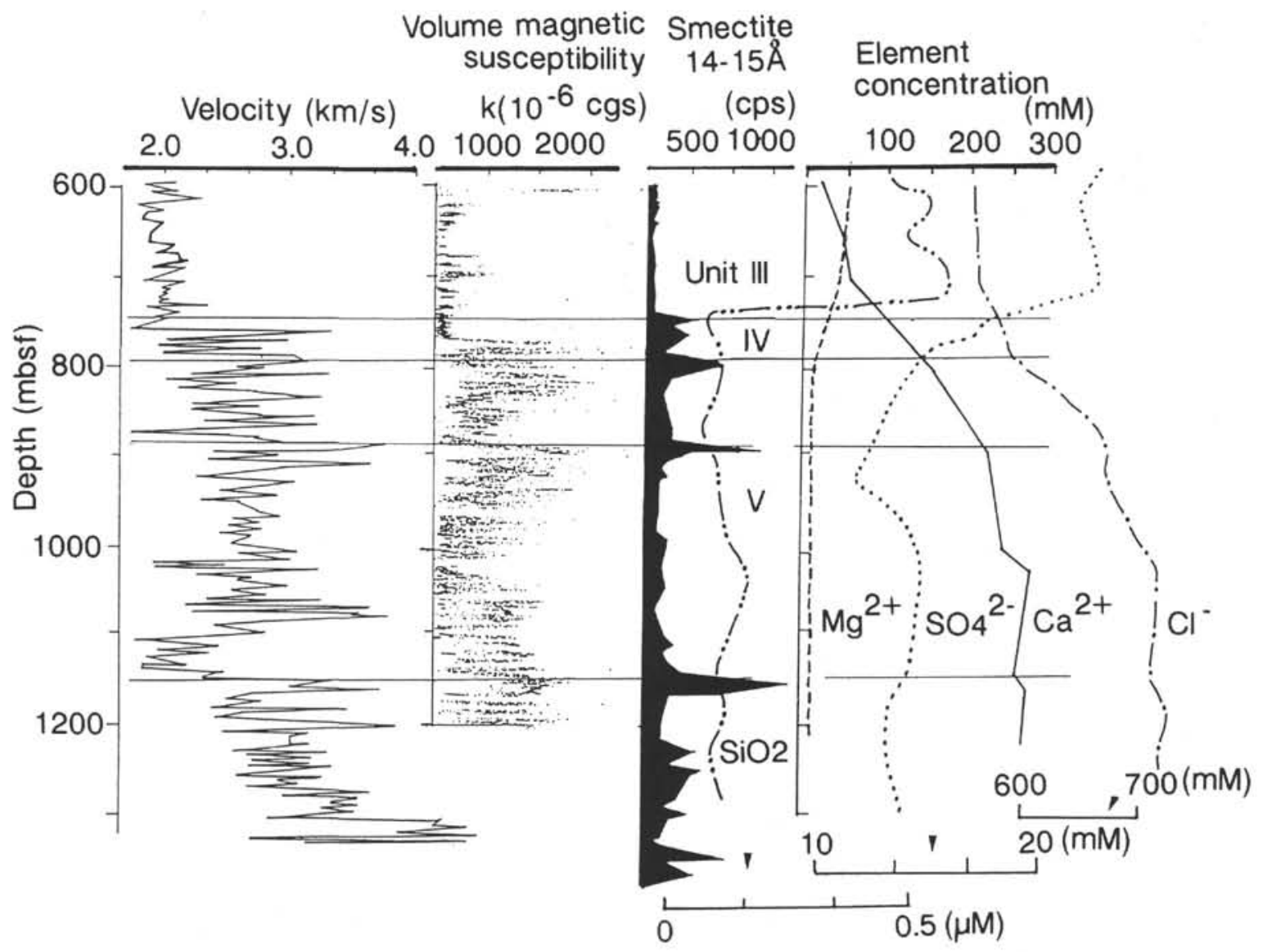

Figure 4. Comparison of smectite contents with physical properties and their pore-water chemistry data from Hole 793B.

\section{Microscopic Observations}

Petrographic observations of the forearc sediments at Sites 792 and 793 reveal that the volcanic glass shards range in color from clear to green or brown. Shapes range from vesicular pumice to glass fragments containing abundant pipe vesicles, to bubble wall shards. The hydrated volcanic glass is inherently unstable and has altered in many cases to palagonite, zeolite, and smectite. The alteration products of volcanic glass appear first on the outside of the shard and grow inward.

The secondary production of smectite and zeolites occurs in the sandstone matrix and forms cementing materials at marginal rims or around primary mineral fragments (Figs. 5C and 5D in crosspolarized light). Smectite, zeolite, gypsum, and prehnite also occur in the microfractures in the sandstone (Figs. 5A, 5B, 6, and 7). Usually, the smectite color is dark yellowish green, whereas the zeolite is white. Prehnite is formed in the gypsum matrix (Fig. 5B). Greenish, sand-sized grains of glauconite or celadonite (a hydrated, iron-rich micaceous clay mineral) were also found in fine sandstone at $\approx 1140$ mbsf at Site 793 (Sample 126-793B-58R-2, 94-96 cm). Plagioclase feldspar in the sandstones is altered to both smectite and zeolite and exhibits ghost twin lamellae.

Primary and secondary minerals were observed in further detail using TEM and SEM techniques; some of these observations are shown in Figures 8-12 and discussed briefly below. An upper Oligocene welded tuff from Site 793 (Sample 126-793B-43R-5, 19-21 cm) has aggregates of granular particles on the rough surface of altered feldspar (Fig. 8). Sandstone from the lower Oligocene section at Site 793 (Sample 126793B-58R-2, 94-96 cm) shows bundles of lath-shaped crystals of analcime on the rough surface (Fig. 9). The XRD analyses indicate that the sandstone in the sample was composed of celadonite, dolomite, and analcime. Basaltic andesite breccia from $\approx 1530 \mathrm{mbsf}$ (lower Oligocene; Sample 126-793B-99R-1, 28-30 cm) is composed of smectite, 7- $\AA$ clay minerals, calcite, feldspar, and celadonite, showing the alteration of glass to smectite (Fig. 10). The surface of the sample was covered with flaky smectites (arrow in Fig. 10A), indicating that alteration began from the outside of the shard.

The TEM analyses of altered feldspar in a hyaloclastic breccia at $\approx 1665$ mbsf (Sample 126-793B-113R-2, 63-65 cm) revealed flaky, smectite formation on the surface (Fig. 11A). The smooth surface was changed to a rough surface with smectite formation, although the outline of the feldspar was preserved (arrows in Fig. 11A). Highresolution TEM photomicrographs show lattice images of smectite with 15 - $\AA d$-spacings on the surface of porphyritic lava from $\approx 1655$ mbsf (Sample 126-793B-112R-1, 110-112 cm; Fig. 11B). X-ray diffraction analysis of the sample indicates that smectite, mica group minerals, quartz, and feldspar are the dominant minerals. Some of the smectite on the altered feldspars do not have the typical flaky morphology, but form crinkled spherical forms (Fig. 12B). The pseudomorph lamellae of the feldspar are still preserved on the surface (Fig. 12A). Deformation of lamellae structure, occurring in crinkle spherules 100 nanometers (nm) in diameter, is seen on the TEM photomicrographs.

\section{SUMMARY AND DISCUSSION}

Several examples of the alteration mineralogy of sediments and rocks cored at Sites 792 and 793 in the Izu-Bonin forearc basin during Leg 126 have been described in this report. The XRD and the optical, SEM, and TEM microscopic analyses of the sediments indicate the occurrence of both diagenetic and low-temperature hydrothermal alteration processes at these sites. The bulk and clay mineralogical 


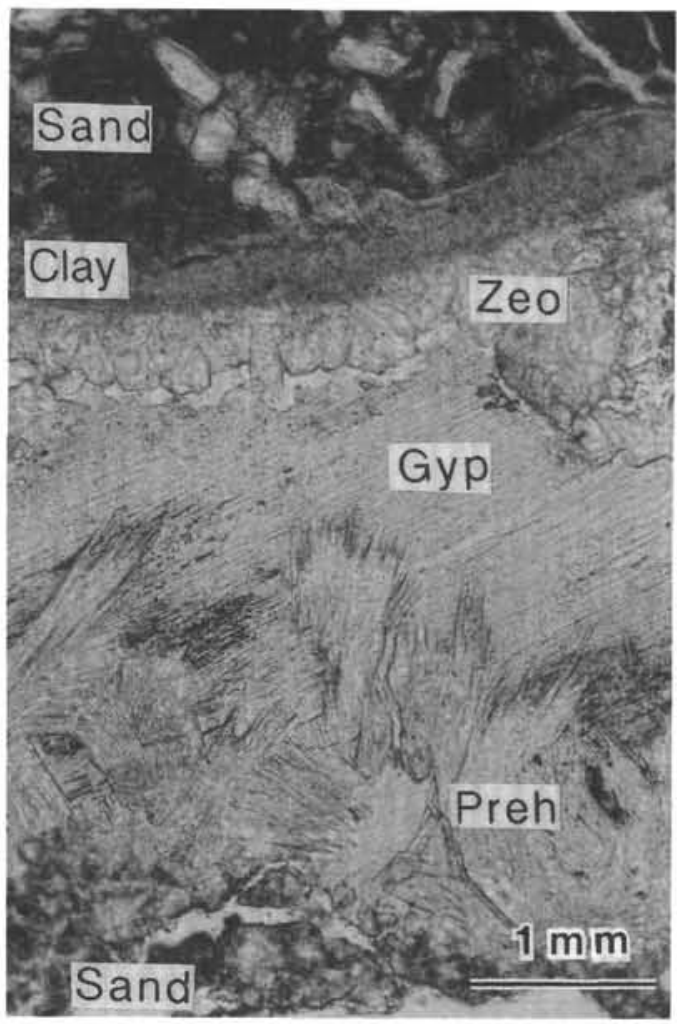

A

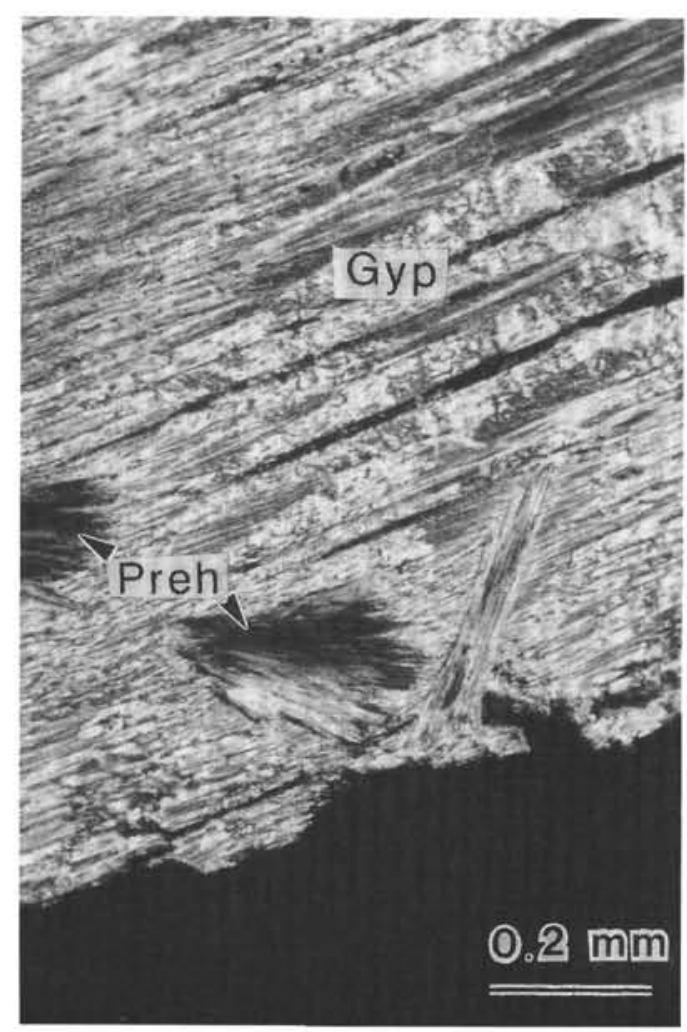

B

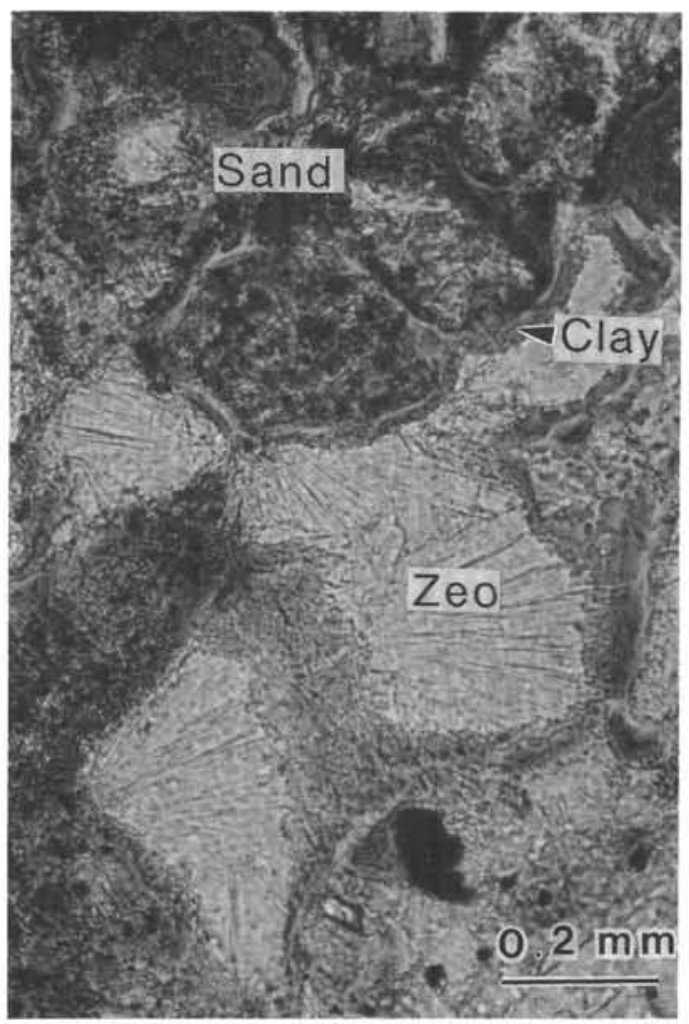

C

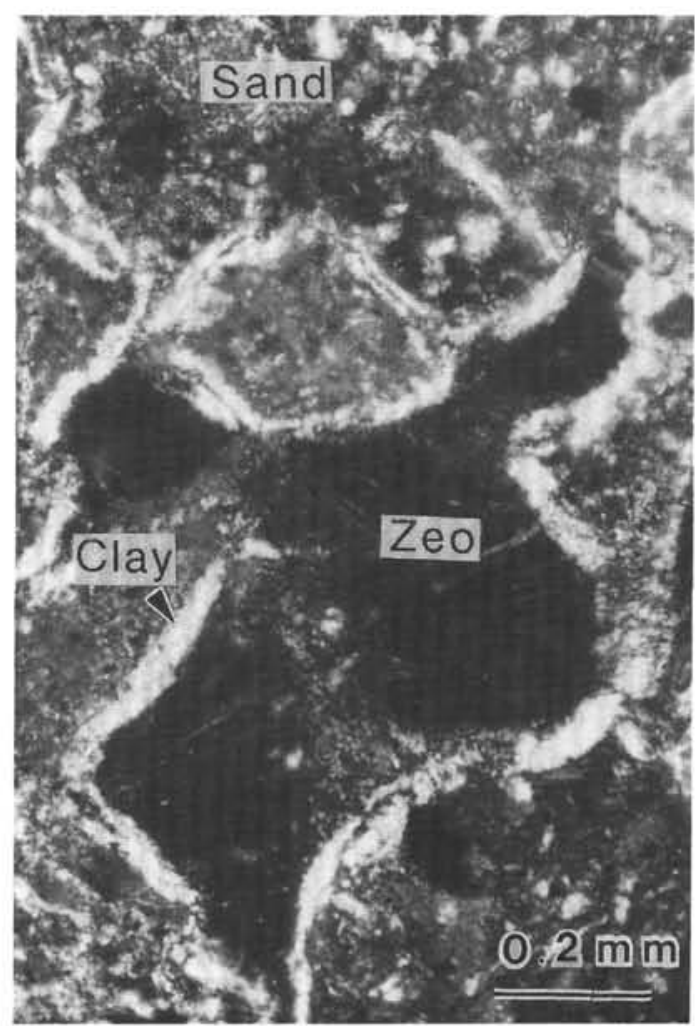

D

Figure 5. Photomicrograph of a thin section of a sandstone in Sample 126-793B-27R-3, 87-89 cm. A, B. Microfractures in the sandstone filled with clays, zeolite (zeo), gypsum (gyp), and prehnite (preh). C, D. Sandstone cemented by clays and zeolite in the matrix. 


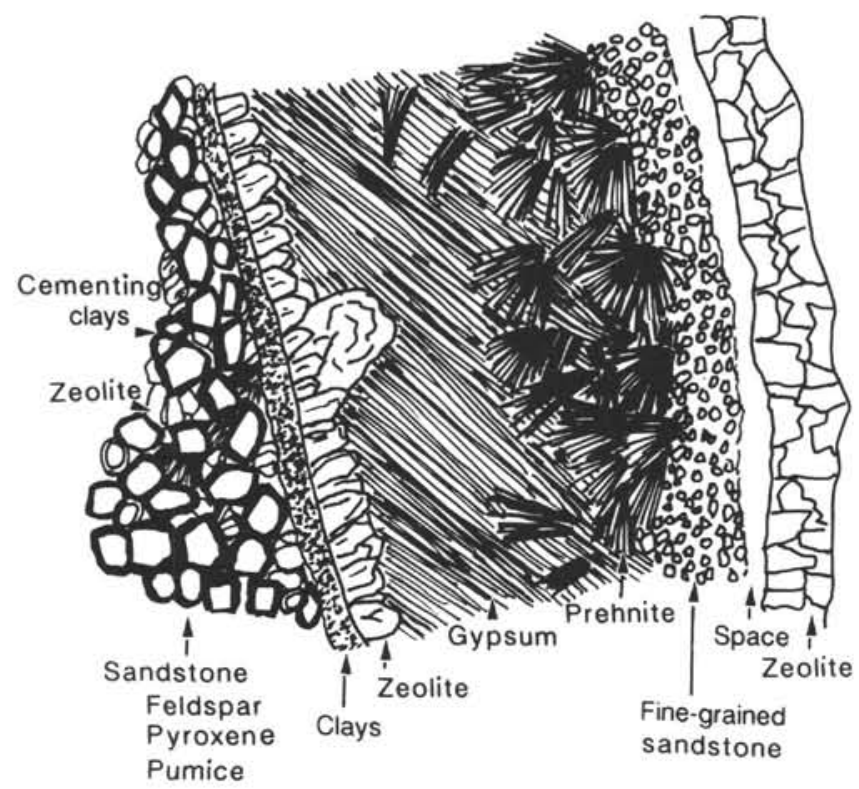

Figure 6. Schematic of the mineral assemblage in the microfracture of Sample 126-793B-27R-3, 87-89 cm.

changes are reflected to some extent in the chemical and physical characteristics of the sediments and the pore-water chemistry. Smectite, zeolite, and gypsum concentrations are high in the vitric and pumiceous sand/sandstone and pumiceous gravel of late Oligoceneearly Miocene age. Formation of these authigenic minerals as cementing materials between grains suggest hydrothermal circulation of pore water occurred below $430 \mathrm{mbsf}$ at Site 792 and below $786 \mathrm{mbsf}$ at Site 793; an idea supported by the extensively altered pore waters at these sites (Taylor, Fujioka, et al., 1990).

Electron microscope observations of these minerals indicate the following alteration processes of volcanic glass and feldspar:

$$
\begin{gathered}
\text { glass } \rightarrow \text { palagonite, smectite, zeolite } \\
\text { plagioclase } \rightarrow \text { smectite, zeolite }
\end{gathered}
$$

The presence of wairakite is important because it indicates that temperatures of alteration may have been in excess of $200^{\circ} \mathrm{C}$, as suggested by other laboratory and petrographic analyses (Coombs et al., 1959; Liou, 1971; Kristmannsdottir, 1976; Natland, 1978; Nakajima and Ueda, 1990). Furthermore, prehnite and gypsum were also observed in the clayey siltstone at $\approx 840 \mathrm{mbsf}$ at Site 793 (Sample 126-793B-27R-3, 87-89 cm), suggesting formation temperatures of $200^{\circ}-300^{\circ} \mathrm{C}$ at and below this depth at this site. The presence of chlorite at Site 793 between 700 and 900 mbsf (indicative of temperatures of $150^{\circ} \mathrm{C}$; Elders et al., 1979) suggests that alteration in the deeper forearc sediments occurred at least at $200^{\circ} \mathrm{C}$ and probably closer to $300^{\circ} \mathrm{C}$. The calcium and sulfate concentrations in the pore water were controlled to a large extent by the precipitation of gypsum and anhydrite. On the basis of the mineral associations seen in this study, the other authigenic minerals were derived from both hydrothermal circulation and alteration of glass and feldspars at temperatures of $200^{\circ}-300^{\circ} \mathrm{C}$.

The SEM and TEM studies showed two kinds of morphology of smectites: typical flaky crystalline smectite and a new "crinkly" type of spherical smectite. The different smectite morphologies may be related to differences in source, degree of diagenesis, or different chemical composition.

\section{ACKNOWLEDGMENTS}

We thank Ms. Bettina Domeyer (Germany) for her XRD assistance. This study was partially supported by Grant No. 01430010 from the Natural Science Research Fund, administered by the Monbusho (Japanese Ministry of Education, Science and Culture). K. Tomita and $\mathrm{K}$. Oinuma reviewed the manuscript.

\section{REFERENCES}

Coombs, D. S., Ellis, A. J., Fyfe, W. S., and Taylor, A. M., 1959. The zeolite facies, with comments on the interpretation of hydrothermal syntheses. Geochim. Cosmochim. Acta, 17:53-107.

Elders, W. A., Hoagland, J. R., McDowell, S. D., 1979. Hydrothermal mineral zones in the geothermal reservoir of Cerro Prieto. In Elders, W. A. (Ed.), Geology and Geothermics of the Salton Trough (GSA Guidebook): Riverside, CA (Campus Museum Contrib.), 5:36-43.

Gill, J. B., Torssander, P., Lapierre, H., Taylor, R., Kaiho, K., Koyama, M., Kusakabe, M., Aitchison, J., Cisowsky, S., Dadey, K., Fujioka, K., Klaus, A., Lovell, M., Marsaglia, K., Pezard, P., Taylor, B., and Tazaki, K., 1990. Explosive deep water basalt in the Sumisu backarc rift. Science, 248:1214-1217.

Kristmannsdottir, H., 1976. Types of clay minerals in hydrothermally altered basaltic rocks, Reykjanes, Iceland. Jokull, 26:30-39.

Leg 126 Scientific Drilling Party, 1989. ODP Leg 126 drills the Izu-Bonin Arc. Geotimes, 34:36-38.

Leg 126 Shipboard Scientific Party, 1989. Arc volcanism and rifting. Nature, $342: 18-20$.

Liou, J. G., 1971. Pressure-temperature stabilities of laumontite, wairakite, lawsonite, and related minerals in the system $\mathrm{CaAl}_{2} \mathrm{Si}_{2} \mathrm{O}_{8}-\mathrm{H}_{2} \mathrm{O}$. J. Petrol., 12:379-411.

Nakajima, W., and Uyeda, S., 1990. Syntheses of natural zeolites: syntheses of heulandite-clinoptilolite, analcime-wairakite, mordenite and ferrierite. Nendo Kagaku, 30:57-75.

Natland, J. H., 1982. Hydrothermal alteration of basalts and sediments at Deep Sea Drilling Project Site 456, Mariana Trough. In Hussong, D. M., Uyeda, S., et al., Init. Repts. DSDP, 60: Washington (U.S. Govt. Printing Office), 759-766.

Pezard, P., Lovell, M., and ODP Leg 126 Shipboard Scientific Party, 1990. Downhole images: electrical scanning reveals the nature of subsurface oceanic crust. Eos, 71:709.

Taylor, B., Fujioka, K., et al., 1990. Proc. ODP, Init. Repts., 126: College Station, TX (Ocean Drilling Program).

Date of initial receipt: 9 October 1990

Date of acceptance: 23 September 1991

Ms 126B-121 


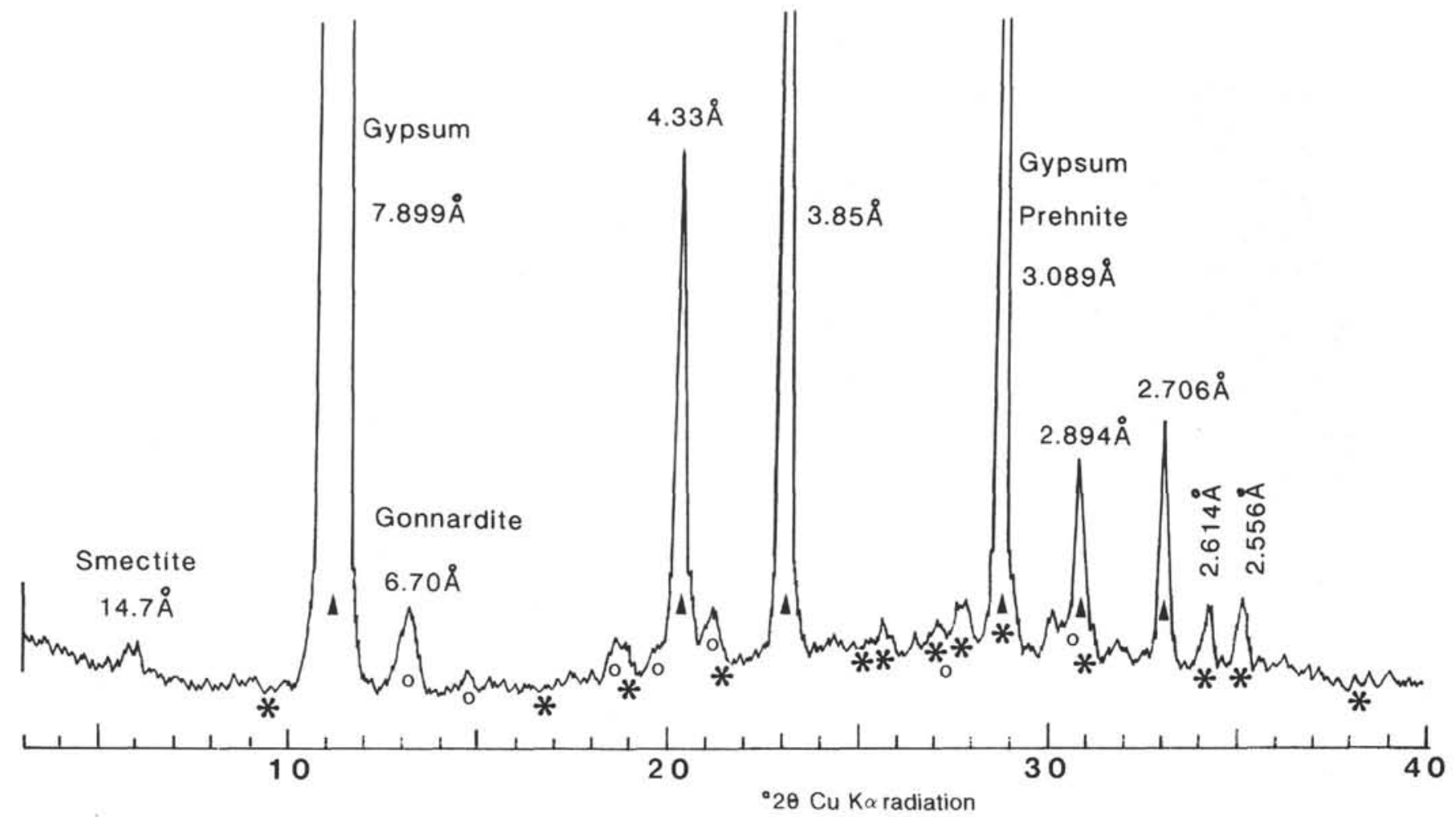

Figure 7. X-ray powder diffraction of the materials filling in the microfracture at Sample 126-793B-27R-3, 87-89 cm. 

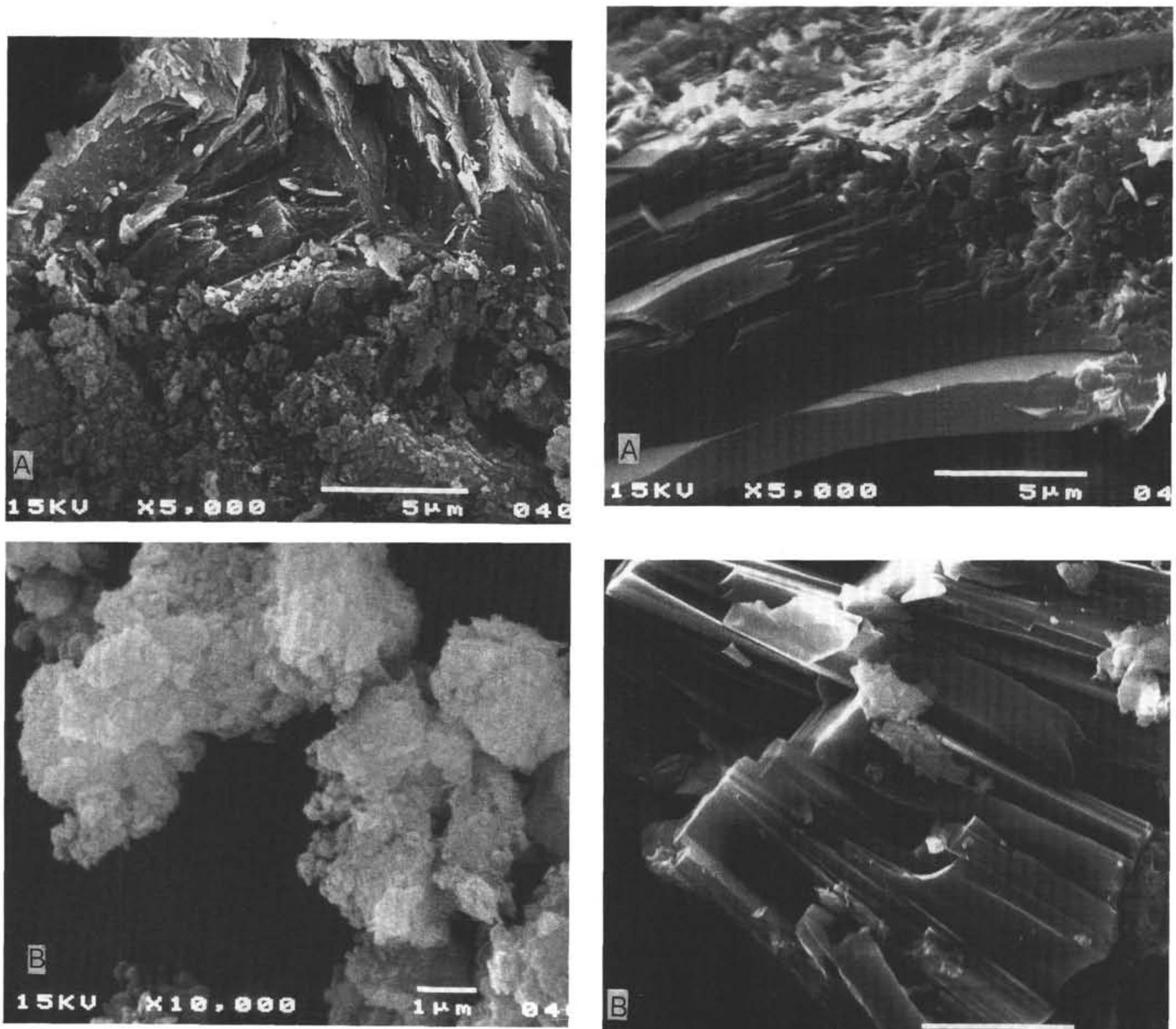

Figure 8. A. Scanning electron micrographs of a welded tuff in Sample 126-793B43R-5, 19-21 cm. B. Higher magnification of Figure 8A, showing granular particulates.

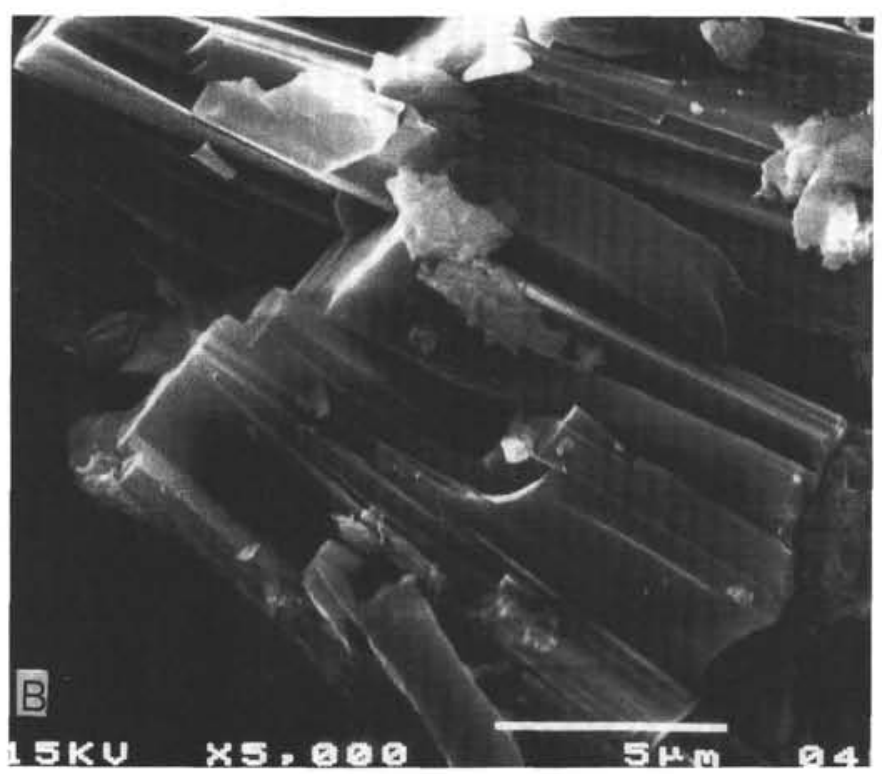

Figure 9. A. Scanning electron micrographs of sandstone in Sample 126-793B58R-2, 94-96 cm, composed of celadonite, dolomite, and analcime. B. Higher magnification of Figure 9A, showing bundles of lath crystals consisting of analcime. 

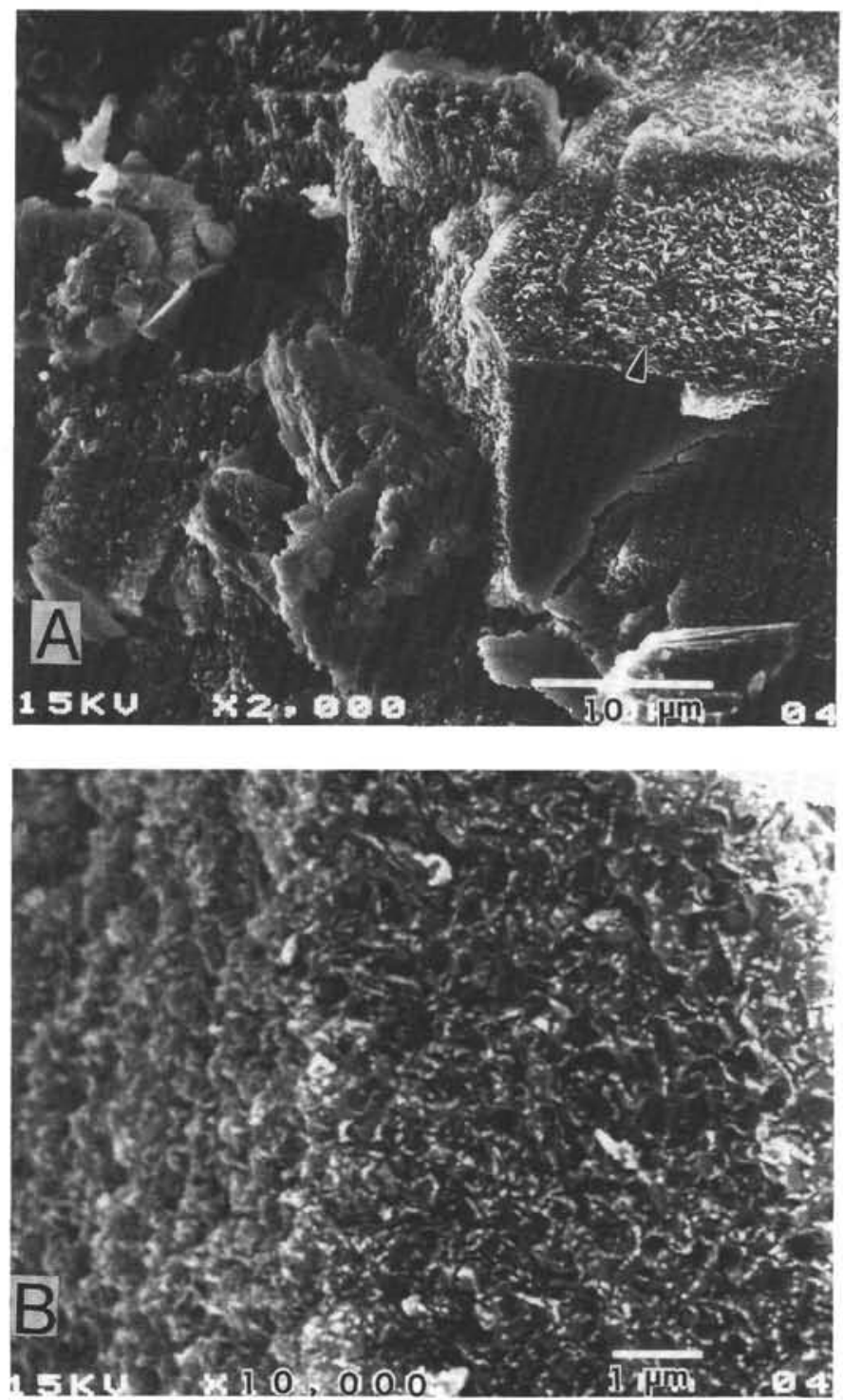

Figure 10. A. Scanning electron micrographs of basaltic-andesite breccia in Sample 126-793B-99R-1, 28-30 cm, composed of smectite, 7- $\AA$ minerals, calcite, feldspars, and celadonite. The feldspar was altered to smectite (arrow) showing flaky surface (Fig. 10B). B. Higher magnification of Figure 10A. 

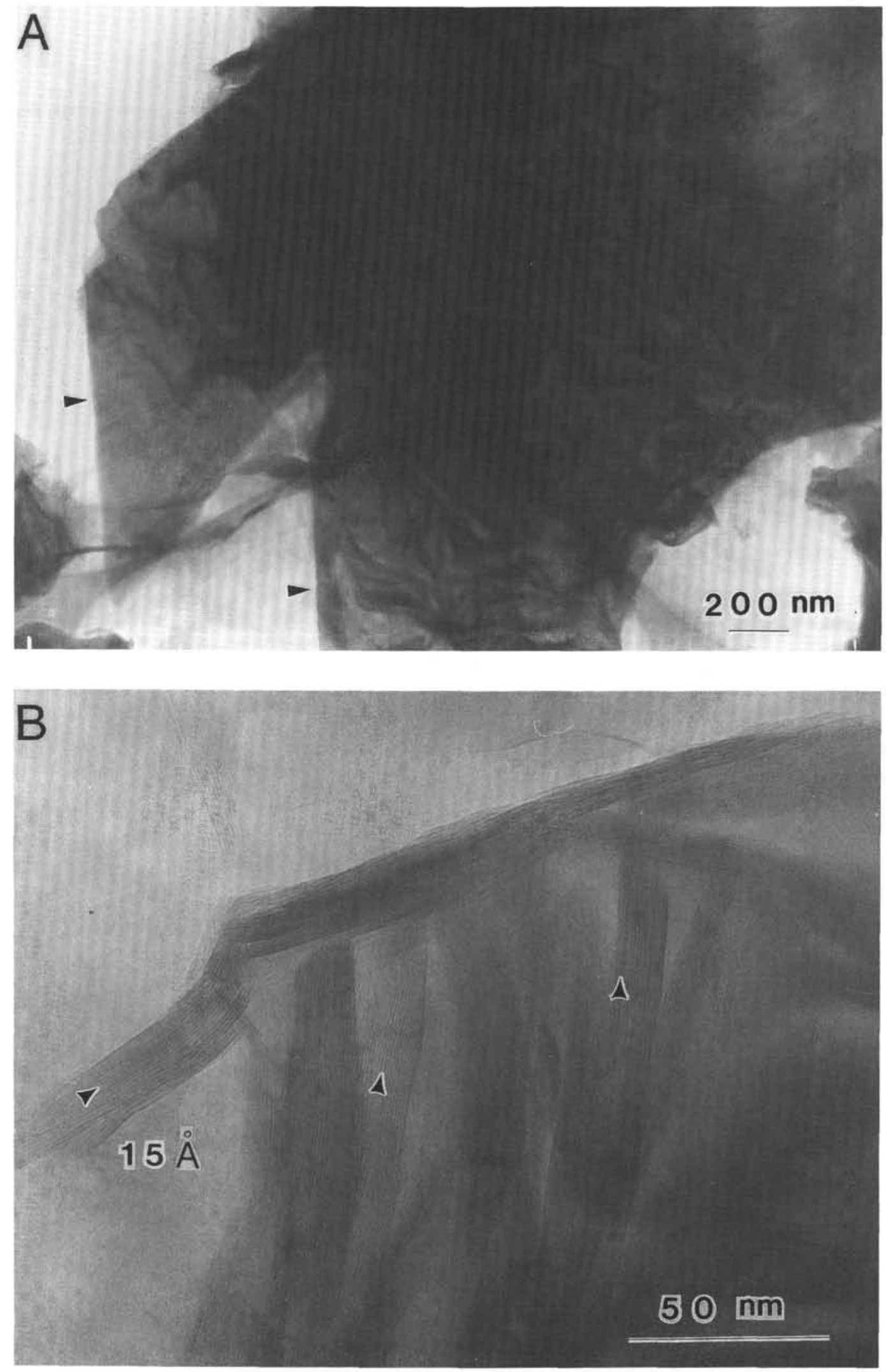

Figure 11. Transmission electron micrographs of (A) hyaloclastite breccia and (B) porphyritic lava at Hole 793B, both of which are altered to smectites. Straight-edged outlines were preserved as shown in Figure 11A (arrows). High-resolution TEM reveals lattice images of $d$-spacings (001) of smectite (Fig. 11B) (arrows). A. Sample 126-793B-113R-2, 63-65 cm, composed of smectite, 10- and 7- $\AA$ minerals, and feldspars. B. Sample 126-793B-112R-1, 110-112 cm, composed of smectite, 10-Å minerals, quartz, and feldspars. 

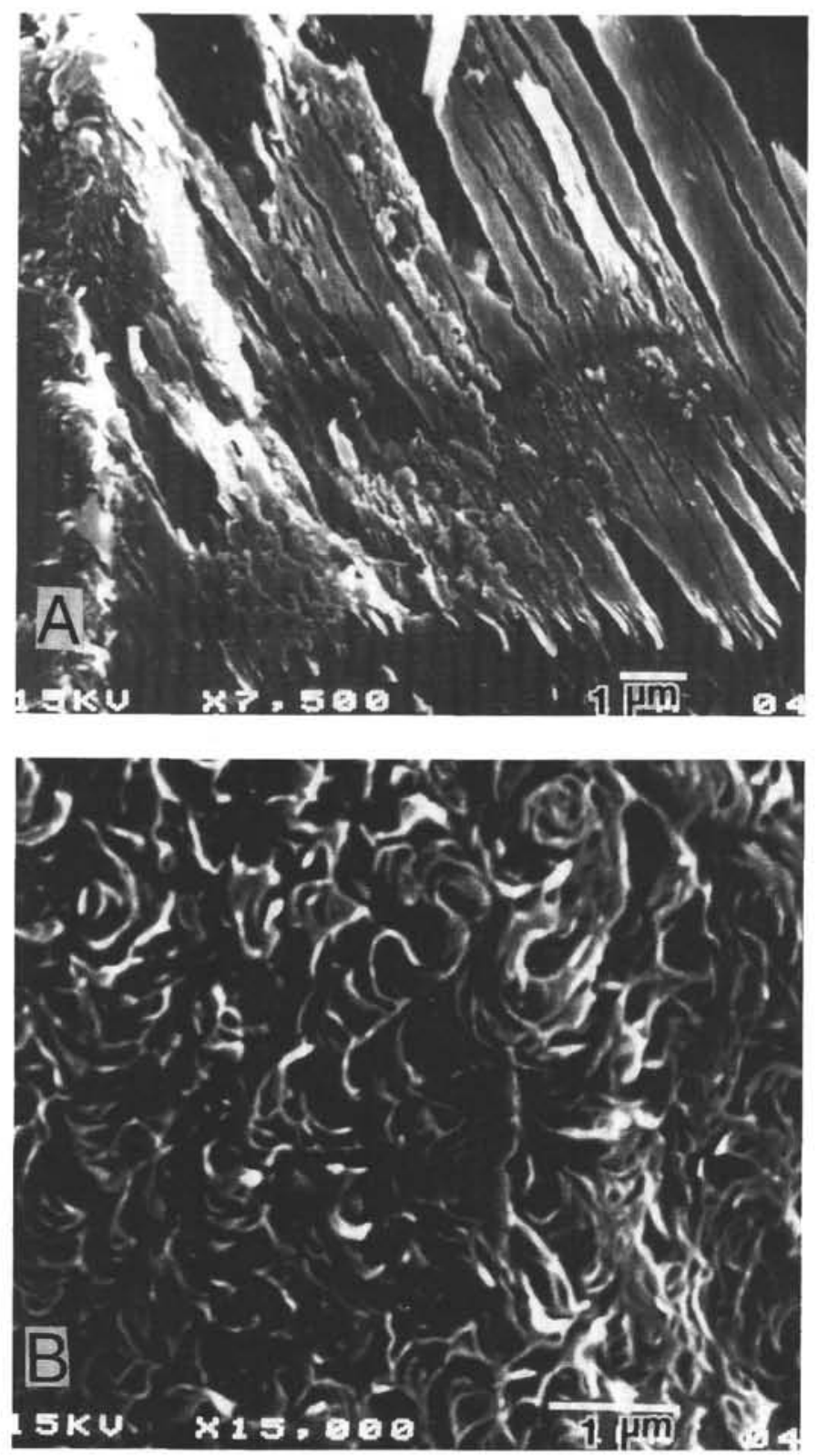

Figure 12. Scanning electron micrographs of altered feldspar producing smectite on the surface (Sample 126-793B-114R-1, 101-103 cm). Pseudomorph lamellae are preserved (A) and are composed of "crinkly" smectite under higher magnification (B). 